\title{
New Zealand's Takeovers Regulation: The Unresolved Debate
}

\author{
Peter Fitzsimons
}

$\mathrm{N}$ EW ZEALAND'S corporate and securities law regime was updated in 1993 with the passing of 23 pieces of legislation. One of the new statutes was the Takeovers Act 1993. The passing of this Act did not constitute the start of a new era in regulation of the securities markets, but rather was one more step in a debate that started in the early 1980s.

The regulation of takeovers usually comprises four requirements. Two of these requirements are that advance notice of an offer must be provided to the target company and the target shareholders, and that the bidder must provide specified information on the proposed bid (these are known as 'pause and publicity' requirements). The two other requirements are that the takeover offer must be made to all holders of a class of shares (a 'mandatory offer' provision), and that the price offered by a bidder to all holders of a class of shares must be the same (an 'equal price' provision).

The debate in New Zealand has primarily centred on whether a takeovers code should contain 'mandatory offer' and 'equal price' provisions, which New Zealand's takcover law still does not include. Equivalent laws in Australia and the United Kingdom, in contrast, contain these provisions, together with pause and publicity requirements (Austin, 1993; Lee, 1993).

This article provides an overview of the debate surrounding takeovers regulation in New Zealand during the late 1980s and 1990s. The New Zealand evidence is consistent with evidence from other countries showing that takeovers are wealth creating. However, the concentrated shareholdings that are a feature of New Zealand's stockmarket may lead to inefficiencies in the market as well as concerns about the protection of minority shareholders in the absence of regulation.

\section{The Takeovers Regime in New Zealand Before 1994}

Takeovers in New Zealand are governed by a mixture of legislative, common law and listing rules. They are also affected by the Overseas Investment Regulations, the Commerce Act 1986 (which governs the competition aspects of mergers and acquisitions), and the Securities Amendment Act 1988 (which requires disclosure of holdings of 5 per cent or more of relevant interests in voting securities, and prohibits insider trading) (Fitzsimons, 1993, 1995).

Peter Fitzsimons is Senior Lecturer in Law at The University of Waikato. 
The major statute on takeovers is the Companies Amendment Act 1963, which regulates process and is referred to as a 'pause and publicity statute' (Takeovers Panel, 1995). It provides for a mandatory period of notice, and for details of the offer to be given to shareholders of the target company where the takeover offer is made in writing, but does not regulate oral offers or stands in the market. ${ }^{1}$ It does not control the price to be offered, nor does it require equal treatment of holders of the same class of shares. Neither does it prohibit partial bids. The Act is utilised in limited circumstances, such as when a bidder faces a widespread shareholding in a target company, is concerned to acquire complete control of a company, or is making a scrip, partial or conditional offer (McKenzie, 1995). Consequently, the Act has only a marginal impact upon takeover regulation.

In 1981 the New Zealand Stock Exchange (NZSE) introduced a takeovers code into its listing rules. The code provided that all shareholders of the same class of shares were to be treated 'similarly' by the offerer, and required that subsequent offers to shareholders be made on 'no less favourable terms' to prior offers made when a takeover was 'reasonably in contemplation'. Any increase in the amount offered for shares, whether on the market or by private treaty, had to be passed on to other offerees, whether or not there had already been an acceptance.

The code as a whole was of limited effect: as its sanctions applied only to listed companies, offers made by private individuals or non-listed corporations were not susceptible to the NZSE's sanctions (Fitzsimons, 1994a). In addition, where a takeover took place in breach of the listing rules, a threat to delist the target company would harm the shareholders who had not taken up the offer. The code was criticised as being largely ineffective (NZSC, 1988), but its provisions were essentially repeated in the 1989 edition of the listing rules.

\section{Reform Proposals in the 1980s and 1990s}

During 1986-89 stockmarket activity in New Zealand substantially increased, and in 1986 the Minister of Justice asked the New Zealand Securities Commission (NZSC) to undertake a review of insider trading and takcovers (Fitzsimons, 1994b). The NZSC put forward two arguments for mandatory offers and equal price provisions. First, shareholders should be treated equally since the corporate contract to which the shareholders are a party provides for all shares to be ranked pari passu. As a result, any premium above the market price that a bidder paid should be shared by all shareholders, not just those who had a significant or controlling interest in a company. Second, "Takeover procedure should allow open competition for the control of a listed company ... to operate in an informed and public securities market'. The aim was to 'bring forth the highest competitive bid for control, and to enable the target shareholders, by an appropriate majority, to make an informed judgment to accept or reject that bid' (NZSC, 1988:80).

\footnotetext{
${ }^{1}$ Multiplex Industries Ltd v Specr [1966] NZLR 122 and Tatra Industries Ltd v Scott Group Ltd [1983] 1 NZCLC 95-079.
} 
The government accepted the NZSC's proposals, but the Cabinet decided to defer it until after the proposed Companies Bill had been introduced (McKenzie, 1993).

The government moved to introduce the Takeovers Bill at the end of 1991. The Bill established a Takeovers Panel, which was given a wide discretion in determining whether any kind of takeover code was needed and, if so, what specific provisions it should contain. The government's economic policies were also evident in this legislation as the Takeover Bill's objectives included providing a code that encouraged an efficient allocation of resources, and competition for corporate control. The Minister of Justice set up a Takeovers Panel Advisory Committee to begin work immediately on the new takeovers code. The Committee issued a draft code for discussion in 1993 which contained notice and pause provisions, as well as a mandatory offer provision and an equal price provision (Takeovers Panel Advisory Committee, 1993).

Opponents of regulation argued that the real issue in the takeover regulation debate was not inequality of treatment of shareholders by bidders but the potential for minority shareholders to be exploited by a successful bidder. Since this issue concerned shareholders' rights and directors' duties, they argued, it should be dealt with by appropriate corporate law (Pound, 1993). In the face of this opposition the government deferred any decision on whether to legislate to enforce the code, on the understanding that the problems that takeovers posed for minority shareholders would be resolved by strengthening shareholders' rights in the new Companies Act 1993.

\section{Developments in 1994-95}

However, the passage of the Companies Act 1993 did not end debate on takeovers law reform. The NZSE's proposed new listing rules in 1994 did not satisfy the Minister of Justice, who appointed a Takeovers Panel to consider a code - a mere three months after the Companies Act came into force.

The Panel reported back with its proposed code in June 1995, which was unchanged from the 1993 final version. The Panel argued that a transfer of control of a large number of companies had taken place without reference to 'all shareholders', and that over 80 per cent of companies on the New Zealand stockmarket had a shareholder who held at least 20 per cent of the voting securities. The Panel pointed out that if the assets of a company had been sold, or if a change in the direction of a company was proposed, then the Companies Act 1993 would have required shareholder approval. The Panel used this requirement to argue that, as control of assets could be also be obtained by acquisition of a controlling interest in a company, a takeover should similarly require shareholder approval or an offer to all shareholders.

The Panel also argued that its proposed code could have a positive impact on foreign investment in New Zealand 'as it provide[d] greater protection and more transparency than existing law' and would provide 'investors from the Pacific Rim 
with protection comparable to that which they enjoyed in their homes markets' (Takeovers Panel, 1995:18).

The code's fundamental rule was that a person was prevented from controlling more than 20 per cent of the voting rights of a company 'unless an offer is made under the Code to all shareholders on the same terms ensuring equal treatment of all shareholders' (Takeovers Panel, 1995:2). The purpose of the 20 per cent limit was to 'ensure that all shareholders [could] participate in the 'transfer of control' (Takeovers Panel, 1995:4). The code was also designed to ensure that corporate control was contestable by requiring a controlling shareholder to make an offer for majority control if that shareholder opposed a hostile bid. The Panel rejected an argument that requiring disclosure would prevent takeovers. In the Panel's view, to the extent that there was free-riding, an auction process would better serve the interests of target shareholders, and in any event a bidder would still benefit if there was a rival bidder to whom it could sell its stake if it wished.

The release of the Panel's recommended code did not end the debate. While the Minister of Justice had indicated that he supported a code, even before the Panel released its report, he failed to persuade the cabinet of the need for it. He then announced that the code would be deferred while further consideration was given to the sufficiency of the NZSE's listing rules as a means to protect minority shareholders.

\section{Evidence Against Mandatory Offer and Equal Price Provisions}

Evidence from other countries suggests that target shareholders experience positive abnormal returns from takeovers, which result from efficiency gains rather than wealth transfers (Romano, 1993). Four studies have been undertaken of the effects of takeovers on shareholder wealth in New Zealand. In its submission on the NZSC's (1983) proposals, the Treasury referred to a study undertaken by Cambie (1983), who measured the average percentage gain above the pre-offer share price for both shareholders of targets and offerers over the period from eight weeks before to two weeks after the announcement of a takeover bid during 1968-81. He found an average gain of 28 per cent for target shareholders and an average loss of minus 3 per cent for bidder shareholders. The Treasury argued that what was important was the overall gain derived, taking gains to the target and bidder as a unit. The Treasury (1984:11) commented:

The fact that most of the gains from takeovers accrue to the target shareholders is consistent with the hypothesis that, at least on the bidder's side, the market for takeovers is a competitive market. If this market were not competitive there would be super-normal profits to be reaped, which would show up as increases in the bidders' stock price at the takeover event. The negative stock price movements from takeover activity may be lower then rates of return to other investment activities. Such findings are not inconsistent, of course, with the proposition that takeovers are, in general, value creating transactions. 
The second study was undertaken by Amery and Emanuel, who examined the share price performance of New Zealand firms that engaged in takeover activity during 1968-85. Amery and Emanuel (1988:15) observed the following:

- In the 51-week pre-offer period, bidder firms outperformed the market. Target and merger firms underperformed the market for most of this period.

- Upon the announcement of an offer, significant and large abnormal gains, averaging 12.8 per cent, accrue to targets. In mergers, the average gain to a firm on an announcement is 6.9 per cent. On the other hand, the market does not appear to react to the bidder firm upon announcement of an offer.

- In the interim period before outcome, the market reacts differently to target firms as uncertainties regarding the success of the offer are resolved. There are gains to shareholders in successfully merged firms, but a portion of the gains to unsuccessful targets is lost. Bidders experience negative abnormal returns on average during this period.

- In the 26-week post-outcome period, both successful bidders and unsuccessful targets experience negative abnormal returns. Unsuccessful bidders have zero abnormal returns. By the end of the post-outcome period, the [Cumulative Average Return] of unsuccessfully targets is approximately zero. It appears that the gains generated on the offer announcement are dependent on the target being combined with another firm.

Amery and Emanuel (1988:57) concluded that:

[t]he results of this study are consistent with a market for corporate control which provides an efficient mechanism for the redeployment of assets to more productive uses or more efficient users as is dictated by changes in technology and consumer preferences.

More recently, Mandelbaum has produced two studies on the impact of takeovers on shareholder wealth. The first of these studies supported the argument that takeovers created wealth since target shareholders experienced positive gains at the time of the takeover announcements which were sustained only if a takeover was successful (Mandelbaum, 1993a). In other cases, a company which had not been taken over initially, but which later received a successful offer, also experienced positive gains. By contrast, a company that received an unsuccessful initial takeover offer which was not followed by a successful one gained abnormal returns only at the time of the announcement, which dissipated once the takeover offer was not accepted. Mandelbaum (1993a:30) concluded that 'the source of gains in takeovers, for New Zealand listed companies during the period 1968-1990, is a result of expected wealth created by the actual takeover offer taking place'. He 
also concluded that there was no 'asymmetric information problem in the sense that bidders' management systematically holds superior information than the market regarding the future prospects of the target firm' (1994:130).

Mandelbaum's second study enquired whether shareholders in a target company are worse off when a full takeover offer is launched by a bidder who has already built a stake in the target company. He aimed to determine whether a mandatory bid rule was necessary in the light of the Takeovers Panel Advisory Committee's inclusion of a rule that, once a person acquired more than 20 per cent of the voting rights in a company, a partial or full offer to all the other shareholders had to be made. Mandelbaum found that, on average, remaining target shareholders 'gained significantly from full successful take-over offers in New Zealand during the period 1985-1990', and that, 'on average, target shareholders (including the minority) are better off as a result of a full take-over compared to their position prior to the bid, albeit to different extents'. He also pointed out that the evidence was 'inconsistent with the proposition that large controlling shareholders used their power to expropriate or consume corporate wealth at the expense of other shareholders' (Mandelbaum, 1993b:7), as one would not expect the controlling shareholders to pay remaining target shareholders positive premiums. As well, he found that the larger the initial stake held by the bidder prior to launching a takeover offer, the lower the premium paid to the remaining target shareholders. A possible reason for this was that, the larger the initial stake, the more likely a takeover becomes and the more heavily this is reflected in the pretakeover price, reflecting the fact that the bidder has paid a differential positive premium for full control.

\section{Evidence Supporting a Takeovers Code}

Supporters of a takeovers code that includes mandatory offer and equal price provisions argue that the differences between the structure of the New Zealand stock market and that of stock markets elsewhere renders irrelevant overseas evidence on the effects of takeovers, particularly as a mechanism to discipline management. The NZSC (1988) had earlier rejected the argument that the stockmarket was efficient in the sense that it incorporated all publicly available information into the share price. As a result, it rejected the argument that takeovers were wealth creating and believed that takeover bids were primarily made for undervalued targets, so that, in the absence of mandatory offer and equal price provisions, takeovers transferred wealth from target shareholders to bidders. This view is undermined by Amery and Emanuel's and Mandelbaum's evidence that gains to target companies' shareprices were dependent upon a successful takeover. If a bidder had identified an undervalued target, the market price should have made a positive gain irrespective of whether the bid was successful, since the market would have then been made aware of the undervaluation.

McKenzie (1995) argues that Mandelbaum's study on the effects of successful takeover bids is of limited value as it deals with bids for all the shares and does not apply to partial bids or to cases of negotiated transfers of a controlling interest. $\mathrm{He}$ 
claims that the New Zealand stockmarket has significant features which need to be taken into account in considering overseas experience. As Mandelbaum (1993a) noted, over 80 per cent of listed companies have one shareholder owning 20 per cent or more of share capital, and 70 per cent of listed companies have one shareholder holding 30 per cent or more of the share capital. This means that corporate control can be transferred in 70 per cent to 80 per cent of listed companies without involving the remainder of those companies' shareholders.

McKenzie then notes the converse of this point: 'it would be difficult for a bidder to acquire control without the consent of the shareholder who holds a 20 per cent plus parcel... This means that in between 70 per cent to 80 per cent of New Zealand listed companies there is no real prospect of a contested takeover and the takeover phenomenon loses its disciplining effect on management' (McKenzie, 1995:2). The Takeovers Panel (1995:3) similarly argues that

Where shares are widely held, an outsider usually cannot accumulate a control parcel without making an offer to all shareholders. The dispersion of share ownership thus tends to promote widespread shareholder participation in a takcover. In these circumstances, the pause and publicity rules enable shareholders to make an informed decision about the merits of an offer.

Evidence from Canada supports this point. Like New Zealand, Canada has a stockmarket with a greater concentration of shareholdings than the United States (Daniels \& Halpern, 1995). This evidence shows that high share-ownership concentration in public firms is correlated with reductions in firm value. This is because accountability problems exist in closely held corporations as well as in widely held corporations (as controlling shareholders may use their position to attain personal perquisites). However, a move to restrict alienability of controlling interests (as the Takeover Panel suggests) could, in such a concentrated market, have perverse effects by encouraging controlling shareholders to retain their shares in order to obtain maximum value from the firm, to the detriment of minority shareholders (Daniels and Halpern, 1995). A feature of the New Zealand market that perhaps ameliorates the impact of concentrated shareholdings is the presence of significant shareholdings by local and overseas institutional shareholders - up to 46 per cent of the shareholdings by 1993 (Walker \& Fox, 1994) - who are not interested in personal perquisites. In Canada the presence of institutional ownership has been associated with shareholder gains, despite the concentrated shareholdings (Daniels \& Halpern, 1995).

McKenzie (1995) identifies two other distinct features of the New Zealand stock market. New Zealand is a small economy with a small stockmarket, without the depth of some overseas markets. And, unlike the United States, New Zealand cannot rely upon shareholder litigation as a means of controlling directors, due to a number of factors including the high costs of litigation, the risk of an award of costs against a plaintiff, and the fact that the size of New Zealand listed companies does 
not justify the litigation relating to the issue of corporate control. McKenzie takes the view that this constraint remains unaffected by the improved shareholder rights and remedies under the Companies Act 1993. Nor has the availability of contingent-fee litigation made any difference, due to 'the litigation culture in New Zealand' (1995:4). This view is supported by research by Ramsay (1995) into corporate litigation in Australia, which shows that shareholder litigation is infrequent and unlikely to be a sufficient enforcement mechanism to control directors. McKenzie is further supported by the lack of enforcement actions by shareholders against alleged insider traders in New Zealand (Fitzsimons, 1995). Although the NZSE's listing rules have provisions preventing transactions with related parties unless there is a prior approval by ordinary resolution, from the point of view of the shareholders these rules suffer from the same drawback as the provisions of the Companies Act 1993 and related legislation: the cost and difficulty of enforcement (Fitzsimons, 1994a). The private right of action provided by the NZSE has been little used, and, as Mandelbaum (1993c) notes, there are a number of barriers to shareholders using these provisions. The NZSE's Market Surveillance Panel lacks statutory powers and is limited to listed companies, while the New Zealand stockmarket does not have the equivalent of the Australian Securities Commission or the Securities and Exchange Commission of the US, which both have regulatory and enforcement roles in their respective jurisdictions (Fitzsimons, 1994c).

McKenzie makes the further point that participants in the United States stockmarket, due to its size, will generally have a continuing presence in the market, with the result that they will wish to protect their reputations in the eyes of shareholders and regulators. By contrast, an acquirer of shares in a company in New Zealand will often be unknown or from an offshore institution. McKenzie also notes that, in the United States, a controlling shareholder may have a fiduciary duty to minority shareholders in a takeover situation, whereas in New Zealand no such duty is imposed.

Gaynor (1995) also argues for a code, on the basis that private, noninstitutional, New Zealand investors had withdrawn from the market. He refers to studies that show such investors have declined in their ownership of the top 40 companies on the New Zealand Stock Exchange. In 1989 such ownership amounted to 40 per cent of this group of companies, but had fallen to 22 per cent by May 1995. By contrast, private investors in Australia increased their shareholding during 1991-94. The decline in the presence of private, noninstitutional, New Zealand investors in the stockmarket was also reflected in the decline of managed funds investment in the top 40 companies from 16 per cent in 1989 to 13 per cent in 1994, which was an alternative means for private, noninstitutional New Zealand investors to invest in the stockmarket. Against this, however, Keenan (1995:21) points out that:

Since the abolition of exchange control and the deregulation of the financial markets, local investors have sensibly moved to diversify internationally instead of putting all their eggs into a tiny $(0.2$ per cent of the world equity 
market) basket. Given that our equity market is amongst the smallest and least diversified of world markets, local investors should diversify more than others. Both private and institutional investors here have diversified internationally. . . Meanwhile, international portfolio investors, regardless of the pro-coders, have invested enthusiastically in our equity and bond markets.

\section{Takeovers Regimes Adopted by New Zealand Listed Companies}

The NZSE's takeovers code required listed companies to choose one of three options for inclusion in their constitutions by 31 December 1995. The three options were: an 'insider only' provision which required 15 days notice of an offer and a report from independent directors where the offer came from the comapny's officers; a 'general notice and pause' provision requiring three days notice of an offer; and a more restrictive 'minority-veto' provision which required shareholders who did not receive an offer or received a lesser offer to hold a meeting to approve the acquisition. By 31 December 1995, 127 companies had determined which regime they would use. Nineteen companies chose the insider-only provision, while 103 companies chose the general notice and pause provision. Only five companies opted for the minority-veto provision. Interestingly, these last companies tended to have relatively open share registers (for example, the largest shareholder of Fletcher Challenge Ltd was the employee unit trust, which held 12.5 per cent of its shares). In a number of cases, directors attempted to have the minority-veto provision adopted but were forced to put forward the general notice and pause provision in the face of opposition mainly from domestic institutional shareholders (Fitzsimons, 1996).

These figures tend to support the view that shareholders who hold substantial, or controlling, interests in a company would support a regime which allowed them to more easily transfer their shares and to obtain any premium for the sale of those interests. Those companies that voted for a minority-veto provision did not have a single controlling shareholder; accordingly, management was not constrained in advocating the minority-veto provision, which operates to ensure that management can more easily defeat a change in control of a company.

In the small number of comapnies that have adopted the minority-veto provision, it was usually supported by the overseas institutional investors. However, 96 per cent of companies adopted one of the two least restrictive regimes at a time when overseas investors had increased their ownership of the New Zealand stockmarket from 4.2 per cent in 1986 to 44 per cent by the end of 1993 (Walker \& Fox, 1994). This suggests that overseas investors are not unduly concerned about the lack of a takeovers code. Ironically, this perhaps supports the Takeover Panel's (1995:18) comment that foreigners pay more attention to economic and political factors than to takeover rules in determining whether to invest in a market.

If New Zealand remains economically and politically stable, it will become evident whether New Zealand's regulatory environment for takeovers has caused 
overseas investors to re-evaluate their investment in New Zealand's stockmarket. The rise in overseas investment during 1986-93 leads one to expect that the absence of a takeovers code will have little or no effect on overseas investment in New Zealand.

\section{Conclusion}

After more than a decade of debate, New Zealand's takeovers regime has not followed the example of overseas jurisdictions. On three occasions, takeovers legislation or regulations have come close to being implemented, only to be deferred at the last moment. The Minister of Commerce, whose department is now responsible for business law reform, could revive the takeovers code at a future date, but this would require either a significant shift in the opinion of the present cabinet or a change of government after the 1996 election.

New Zealand now has a mixture of limited statutory regulation of certain offers under the Companies Amendment Act 1963, and the three possible regimes under the NZSE's 1994 listing rules. These regulations do not require that an offer must be made to all the shareholders or that a bidder must offer the same price to all the holders of the same class of shares. The minority-veto provision, which is the nearest NZSE option to the takeovers code, has been accepted in only a small number of listed companies.

The current regime clearly favours shareholders who have controlling interests in listed companies. However, while there is evidence of the wealth creating effects of takeovers, no evidence has been produced to show that any benefits of the Takeovers Panel's proposed code would be greater than the costs imposed. The concentrated nature of New Zealand's sharemarket makes it doubtful that the current regime will put pressure upon managements to perform or face losing their positions in the absence of a transfer by a controlling shareholder of its interest.

Minority shareholders, who are not at present in a position to protect their own interests, have to hope either that controlling shareholders act so as to increase the value of the company or that institutional shareholders will play a more active role in the management of companies. Unless there are reforms in the area of shareholder protection, greater regulation of takeovers may perhaps be necessary. If this issue could be resolved, the case for greater regulation of takeovers in New Zealand would appear to lack substance. 


\section{References}

Amery, M. \& D. Emanuel (1988), 'Takeover Announcements and Shareholder Returns: New Zealand Experience', Pacific Accounting Review 1: 42-58.

Austin, R. (1993), 'Takeovers-The Australian Experience', pp.144-91 in J. Farrar (ed.), Takeovers: Institutional Investors and the Modemization of Corporate Laws, Oxford University Press, Auckland.

Cambie, K. (1983), Returns from Takeover Sales on the New Zealand Share Market, unpublished M Comm. thesis, University of Auckland.

Daniels, R. \& P. Halpern (1995), 'Too Close for Comfort: The Role of the Closely Held Public Corporation in the Canadian Economy and the Implications for Public Policy', Canadian Business Law Jounal 26(1): 11-62.

Fitzsimons, P. (1993), 'Securities Commission v R. E. Jones', Waikato Law Review 1: 165-76.

- (1994a), 'The New Zealand Stock Exchange: Rights and Powers', pp.534-69 in G. Walker \& B. Fisse (eds), Securities Regulation in Australia and New Zealand, Oxford University Press, Auckland. (1994b), 'The New Zealand Securities Commission: The Rise and Fall of a Law Reform Body',
Waikato Law Review 2: 87-124.

- (1994c), 'Australia and New Zealand on Different Corporate Paths', Otago Law Review 8: 26593.

(1995), 'Enforcement of Insider Trading Laws by Shareholders in New Zealand: Time for Reform', Waikato Law Review 3: 97-126.

- (1996), 'A Race to the Bottom? The Takeovers Regime in New Zealand: An Overview and Comparison with Overseas Jurisdictions', Corporate Law Teachers Conference, Bond University, Queensland.

Gaynor, B. (1995), 'Takeovers Code Needed to Kick Some Life Into Browbeaten NZSE40', National Business Review, 23 June.

Keenan, P. (1995), 'Takeovers Code is No Panacea for the Small Shareholder', National Business Review, 7 July.

Lee, T. (1993), 'Takeovers: The United Kingdom Experience', pp.192-202 in J. Farrar (ed.), Takeovers: Institutional Investors and the Modemization of Corporate Laws Oxford University Press, Auckland.

Mandelbaum, A. (1993a), "The Source of Gains in New Zealand Takeover Offers: Wealth Creation or Merely Undervaluation?', Money and Finance Group, Victoria University of Wellington, Wellington.

(1993b), 'Bidders' Initial Stake in Target Companies and Premiums Paid to Remaining Target Shareholders in New Zealand Full Takeover Offers: Could it Justify a Mandatory Offer Rule?', Money and Finance Group, Victoria University of Wellington, Wellington. 
- (1993c), 'Economic Aspects of Takeovers Regulation with Particular Reference to New Zealand', pp.203-54 in J. Farrar (ed.), Takeovers: Institutional Investors and the Modernization of Corporate Laws, Oxford University Press, Auckland.

- (1994), 'Conceptual and Empirical Review of Takeovers Regulation - New Zealand', Company and Securities Law Journal 12: 124-31.

McKenzie, P. (1993), 'Takeovers - The New Zealand Experience', pp.106-43 in J. Farrar (ed.), Takeovers, Institutional Investors, and the Modernisation of Corporate Law, Oxford University Press, Auckland.

_ (1995), 'Overtaking the Takeovers Debate Before the Undertaker Arrives', Takeovers Seminar, Wellington.

New Zealand Securities Commission (NZSC) (1983), Company Takeovers: A Review of the Law and Practice, Wellington.

- (1988), Company Takeovers: Report to the Minister of Justice by the Securities Commission, Commerce Clearing House New Zealand Ltd, Wellington.

New Zealand Stock Exchange (NZSE) (1994), Listing Rules, Wellington.

Pound, J. (1993), 'Commentary on Draft Takeover Code', New Zealand Takeovers Panel Advisory Committee, Wellington.

Ramsay, I. (1995), 'Enforcement of Corporate Rights and Duties by Shareholders and the Australian Securities Commission: Evidence and Analysis', Australian Business Law Review 23: 174-83.

Romano, R. (1993), The Genius of American Corporate Law, AIE Press, Washington DC.

Takeovers Panel (1995), Report of the Panel on the Takeovers Code, Wellington.

Takeovers Panel Advisory Committee (1993), Draft Takeovers Code, Wellington.

Treasury (1984), Regulation of Company Takeovers: Treasury Submission to the Securities Commission, Wellington.

Walker, G. \& M. Fox (1994), 'Ownership, Structure of New Zealand Stock Market, 1989 to 1993 : Evidence and Implications for Securities Regulation', Journal of Banking Finance Law and Practice 5: 244-50. 